\title{
Lorcaserin and pimavanserin: emerging selectivity of serotonin receptor subtype-targeted drugs
}

\author{
Herbert Y. Meltzer ${ }^{1}$ and Bryan L. Roth ${ }^{2}$
}

\begin{abstract}
1Department of Psychiatry and Behavioral Sciences, Northwestern Feinberg School of Medicine, Chicago, Illinois, USA.
2Department of Pharmacology, University of North Carolina Chapel Hill Medical School, Chapel Hill, North Carolina, USA.
\end{abstract}

\begin{abstract}
Serotonin (5-hydroxytryptamine, or 5-HT) receptors mediate a plethora of physiological phenomena in the brain and the periphery. Additionally, serotonergic dysfunction has been implicated in nearly every neuropsychiatric disorder. The effects of serotonin are mediated by fourteen GPCRs. Both the therapeutic actions and side effects of commonly prescribed drugs are frequently due to nonspecific actions on various $5-\mathrm{HT}$ receptor subtypes. For more than 20 years, the search for clinically efficacious drugs that selectively target 5-HT receptor subtypes has been only occasionally successful. This review provides an overview of 5-HT receptor pharmacology and discusses two recent 5-HT receptor subtype-selective drugs, lorcaserin and pimavanserin, which target the $5 \mathrm{HT}_{2 \mathrm{C}}$ and $5 \mathrm{HT}_{2 \mathrm{~A}}$ receptors and provide new treatments for obesity and Parkinson's disease psychosis, respectively.
\end{abstract}

\section{Serotonin receptors and signal transduction}

Serotonin, which was known to be the principal vasoconstricting substance found in serum, was chemically identified as 5-hydroxytryptamine by Rapport and colleagues in 1948 (1). Although the effects of serotonin on smooth muscle and other peripheral organs were long appreciated, it wasn't until its structural similarity to lysergic acid diethylamide (LSD) was noted that serotonin and its receptors were linked to neurotransmission (2). Distinct serotonin receptor subtypes were proposed in 1957 (3), with the 5-HT1 receptors having high affinity for serotonin and the 5-HT2 receptors having relatively low affinity for 5-HT. The so-called 5-HT1 and 5-HT2 receptors identified pharmacologically by Gaddum and colleagues (3) roughly correspond to what are now known as the $5-\mathrm{HT}_{1}$ and $5-\mathrm{HT}_{2}$ families of receptors (Figure 1 ).

With the development of radioligand-binding technology, multiple distinct serotonin receptors were identified based principally on their differential radioligand-binding properties. Following the cloning of the $\beta$-adrenergic receptor (4), $5-\mathrm{HT}_{1 \mathrm{~A}}$ (5), the first socalled orphan GPCR, was cloned by Brian Kobilka in collaboration with Marc Caron and others $(6,7)$. In rapid succession, the large family of $G$ protein-coupled serotonin receptors we now appreciate were identified by molecular cloning technology and characterized by pharmacological and biochemical studies $(8,9)$, including $5-\mathrm{HT}_{1 \mathrm{~B} / 1 \mathrm{D}}(10)$ and $5-\mathrm{HT}_{1 \mathrm{E}}(11)$, as well as $5-\mathrm{HT}_{2 \mathrm{~A}}(12,13)$ and $5-\mathrm{HT}_{2 \mathrm{C}}(14,15)$, which have lower affinities for 5-HT than the other serotonin receptors. The $5-\mathrm{HT}_{4}$ receptor was also one of the early 5 -HT receptor subtypes identified mainly by radioligand binding and pharmacological studies (refs. 16, 17, and see Figure 1).

In terms of signal transduction and pharmacology, we now know that all members of the $5-\mathrm{HT}_{1}$ family are intronless and couple to the Gi family of heterotrimeric G proteins - in keeping with the original description of the $5-\mathrm{HT}_{1 \mathrm{~A}}$ receptor $(7)$. The

Conflict of interest: Herbert Y. Meltzer is a shareholder of ACADIA Pharmaceuticals and GlaxoSmithKline. He receives, or has received, grant or contract support from, or is, or has been, a consultant to ACADIA, Alkermes, Astellas, BioLineRx, Bristol-Myers Squibb, Dainippon Sumitomo Pharma, Eli Lilly, EnVivo Pharmaceuticals, Janssen Pharmaceuticals Inc., Novartis, Otsuka, Pfizer, Sunovion, and Teva. Bryan L. Roth is a consultant to Pfizer and RuiYi and receives support from Dainippon Sumitomo Pharma.

Citation for this article: J Clin Invest. 2013;123(12):4986-4991. doi:10.1172/JCI70678.
5- $\mathrm{HT}_{1}$ family of receptors has been successfully exploited for the treatment of anxiety and depression with the development of drugs like buspirone (Table 1 ), which is a selective $5-\mathrm{HT}_{1 \mathrm{~A}}$ partial agonist. Likewise, 5- $\mathrm{HT}_{1 \mathrm{~B}}$ and $5-\mathrm{HT}_{1 \mathrm{D}}$ receptors represent canonical targets for antimigraine medications including various ergots (e.g., ergotamine, dihydroergotamine, and methysergide) as well as the more selective tryptans (e.g., sumatryptan and analogs) $(18,19)$. No selective $5-\mathrm{HT}_{1 \mathrm{E}}$ drugs exist and though selective $5-\mathrm{HT}_{1 \mathrm{~F}}$ drugs have been developed, none of them have yet been approved by the FDA (Table 1). Theoretically, $5-\mathrm{HT}_{1 \mathrm{~F}}$ antagonists might represent novel therapeutic agents for migraine headaches.

The 5- $\mathrm{HT}_{2}$ family receptors couple to $\mathrm{Gq} \mathrm{G}$ proteins and modulate phosphoinositide hydrolysis and PKC activation (20-22). 5- $\mathrm{HT}_{2}$ family receptors typically have lower affinity for molecular serotonin than other 5-HT receptors and are often potently inhibited by both typical (12) and atypical (23) antipsychotic drugs (24). 5- $\mathrm{HT}_{2 \mathrm{~A}}$ receptors represent the main serotonin receptors found in platelets, vascular smooth muscle, and the cerebral cortex $(25,26)$. As discussed below, 5- $\mathrm{HT}_{2 \mathrm{~B}}$ receptors are enriched in the heart (27), and drugs likely mediate their valvulopathogenic actions on heart valves via a combination of $G$ protein and $\beta$-arrestin signaling (27-29). The distribution and function of $5-\mathrm{HT}_{2 \mathrm{C}}$ receptors will be summarized below when lorcaserin, a selective $5-\mathrm{HT}_{2 \mathrm{C}}$ agonist, is discussed.

The 5- $\mathrm{HT}_{4}, 5-\mathrm{HT}_{6}$, and 5- $\mathrm{HT}_{7}$ families of receptors are all coupled to the Gs $G$ proteins and mediate the stimulatory effects of serotonin on cAMP accumulation. 5- $\mathrm{HT}_{4}$ receptors represent the main site of action of many drugs used for treating gastrointestinal motility disorders (Table 1) and are found widely distributed throughout the body (18). 5- $\mathrm{HT}_{6}$ and $5-\mathrm{HT}_{7}$ receptors have recently been the subject of intense investigation by pharmaceutical companies based on the discovery that many atypical antipsychotic drugs have high affinities for both receptors (30). As can be seen in Table 1, compounds that target $5-\mathrm{HT}_{6}$ and $5-\mathrm{HT}_{7}$ receptors are currently in testing for depression, cognition enhancement, and psychosis.

Drugs acting on 5-HT receptors display a range of efficacy from full agonists to inverse agonists (e.g., antagonists with negative intrinsic activity). Buspiron, for instance, is a partial agonist at $5-\mathrm{HT}_{1 \mathrm{~A}}$ receptors, whereas sumatriptan is a full agonist at $5-\mathrm{HT}_{1 \mathrm{D}}$ receptors. By contrast, both typical and atypical antipsychotic drugs have inverse agonist actions at many 5-HT receptor subtypes including 


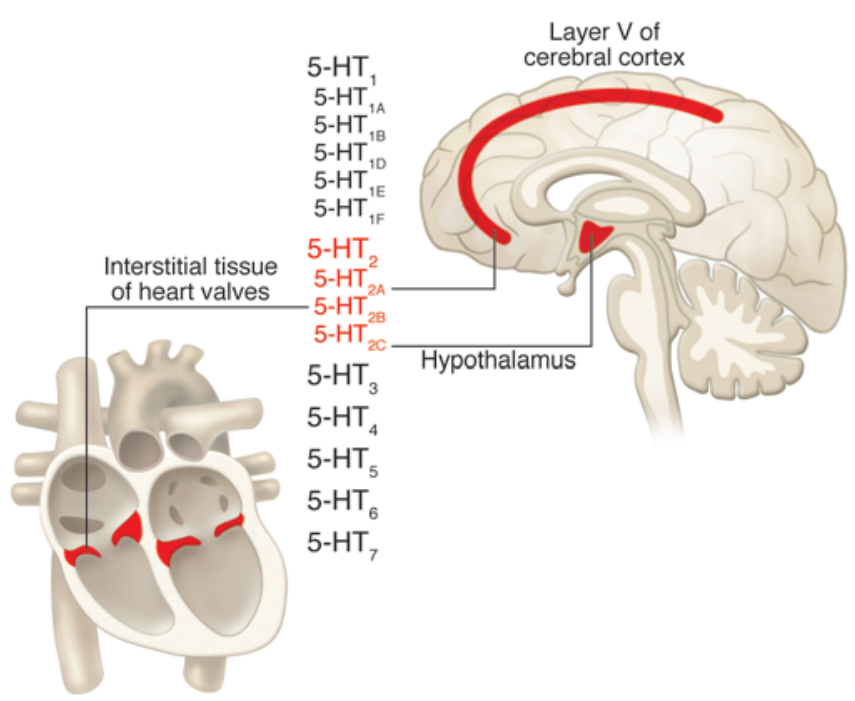

5- $\mathrm{HT}_{2 \mathrm{~A}}(31)$ and $5-\mathrm{HT}_{2 \mathrm{C}}(32)$. Inverse agonists represent drugs that antagonize the action of full agonists (e.g., are "antagonists") and simultaneously lower the basal level of receptor signaling (e.g., suppress constitutive receptor activity; see ref. 33 for review). Essentially, inverse agonists are antagonists with negative intrinsic activity. Finally, drugs like ergotamine display functional selectivity or signaling bias for many $5-\mathrm{HT}$ receptors including $5-\mathrm{HT}_{2 \mathrm{~B}}(28,29)$. Thus, ergotamine has much higher potency for activating $\beta$-arrestin pathways than for activating $G$ protein-mediated signaling $(28,29)$ and as such is considered to display functional selectivity for $\beta$-arrestin signaling and to represent a $\beta$-arrestin-biased agonist.

Because of the vast effort devoted over the past five decades to studying serotonin and classifying its receptors, we now appreciate that serotonin is involved in the regulation of nearly every CNS function, including cognition, autonomic function, perception, emotion, appetite, aggression, and mood, to name but a few (18).

\section{Figure 1}

Sites of action of 5-HT therapeutics. Shown in the middle is a table listing the major families of $5-\mathrm{HT}$ receptors (viz. $5-\mathrm{HT}_{1}$ to $5-\mathrm{HT}_{7}$ ). As shown, the $5-\mathrm{HT}_{1}$ family has five members $\left(5-\mathrm{HT}_{1 \mathrm{~A}}, 5-\mathrm{HT}_{1 \mathrm{~B}}, 5-\mathrm{HT}_{1 \mathrm{D}}\right.$, $5-\mathrm{HT}_{1 \mathrm{E}}$, and $5-\mathrm{HT}_{1 \mathrm{~F}}$ ), while the $5-\mathrm{HT} 2$ family - the topic of this review - has three: $5-\mathrm{HT}_{2 \mathrm{~A}}, 5-\mathrm{HT}_{2 \mathrm{~B}}$, and $5-\mathrm{HT}_{2 \mathrm{C}}$. Each member of the $5-\mathrm{HT}_{2}$ family displays distinct brain and tissue distributions. The $5-\mathrm{HT}_{2 \mathrm{~A}}$ receptor is enriched in pyramidal neurons in layer $\mathrm{V}$ of the cerebral cortex, where it mediates the actions of pimavanserin and other atypical antipsychotic drugs. The $5-\mathrm{HT}_{2 \mathrm{~B}}$ receptor is enriched in interstitial cells of the heart valves, where it mediates the valvulopathic actions of certain drugs like fenfluramine. The $5-\mathrm{HT}_{2 \mathrm{C}}$ receptor is enriched in the hypothalamus, among other areas, particularly in nuclei engaged in regulating feeding behavior, where it mediates the actions of the appetite suppressant lorcaserin.
Additionally, alterations in serotonergic neurotransmission have been implicated in nearly every neuropsychiatric disorder, including schizophrenia and related psychotic disorders, major depression, eating disorders, and so on (18). Many of the therapeutic actions, as well as serious side effects of commonly prescribed medications, are due to nonspecific actions on 5-HT receptor subtypes $(18,27,34)$. Given this wealth of evidence implicating altered serotonergic neurotransmission in neuropsychiatric disease, as well as the plethora of 5-HT receptor subtypes, it has long been proposed that drugs that target distinct 5-HT receptors might provide novel and effective treatments for many neuropsychiatric disorders (Table 1).

Despite the abundant evidence suggesting that selective serotonergic drugs would prove efficacious for many diseases, a fundamental challenge encountered for creating them relates to the relatively similar binding pocket shared among 5-HT receptor subtypes. As seen in recent high-resolution structures derived from the

\section{Table 1}

Listed are approved/investigational drugs targeting distinct 5-HT receptor subtypes

\begin{tabular}{|c|c|}
\hline Receptor subtype & Known indications (medication name) \\
\hline $5-\mathrm{HT}_{1 \mathrm{~A}}$ & $\begin{array}{l}\text { Anxiety, depression } \\
\text { (buspirone) }\end{array}$ \\
\hline $\begin{array}{l}5-\mathrm{HT}_{1 \mathrm{~B}} \\
\text { and 5-HT }\end{array}$ & $\begin{array}{c}\text { Migraine headaches } \\
\text { (sumatriptan, rizatriptan, zolmitriptan, etc.) }\end{array}$ \\
\hline $5-\mathrm{HT}_{1 \mathrm{E}}$ & Unknown \\
\hline $5-\mathrm{HT}_{1 \mathrm{~F}}$ & Migraine headaches \\
\hline $5-\mathrm{HT}_{2 \mathrm{~A}}$ & Hypertension (ketanserin) \\
\hline $5-\mathrm{HT}_{2 \mathrm{~B}}$ & $\begin{array}{l}\text { Pulmonary hypertension } \\
\text { (terguride) }\end{array}$ \\
\hline $5-\mathrm{HT}_{2 \mathrm{C}}$ & Obesity (lorcaserin) \\
\hline $5-\mathrm{HT}_{3}$ & $\begin{array}{c}\text { Chemotherapy-induced nausea } \\
\text { (odansetron, granisetron,tropisetron, etc.) }\end{array}$ \\
\hline $5-\mathrm{HT}_{4}$ & $\begin{array}{l}\text { Gastrointestinal motility disorders } \\
\text { (metoclopramide) }\end{array}$ \\
\hline $5-\mathrm{HT}_{5}$ & Unknown \\
\hline $5-\mathrm{HT}_{6}$ & NA \\
\hline $5-\mathrm{HT}_{7}$ & NA \\
\hline
\end{tabular}

Potential new indications (medication name)

Cognition enhancement (tandospirone) Depression (AZD3783)

$$
\begin{gathered}
\text { NA } \\
\text { NA } \\
\text { Psychosis (pimavanserin) }
\end{gathered}
$$$$
\text { Fibrosis (NA) }
$$

Psychosis, mood disorders, anxiety, metabolic syndrome

NA

Dementia (NA)

NA

Cognition enhancement in

Alzheimer's disease, psychosis (SB-742457)

Depression, anxiety (NA)
References

This article 


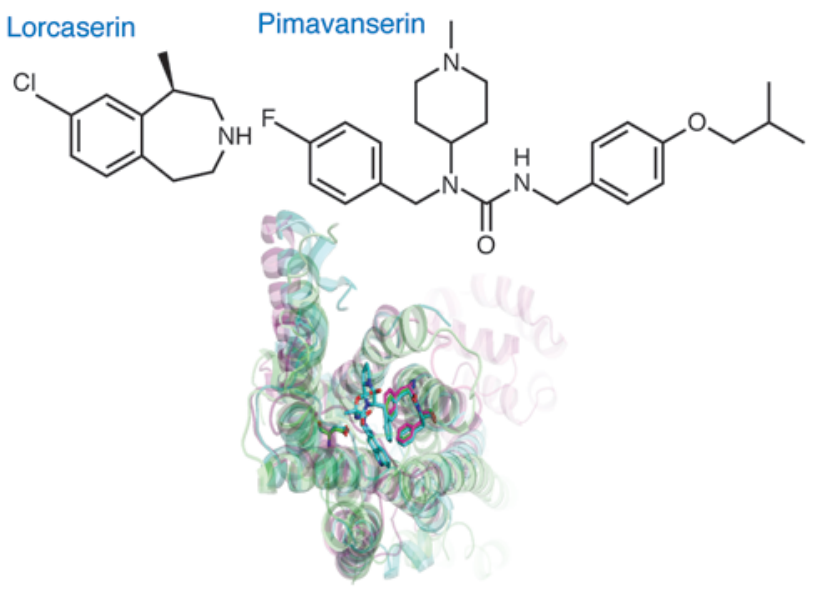

\section{Figure 2}

Structures of lorcaserin and pimavanserin in relationship to the serotonin receptor-binding pocket. Shown at the top are the structures of lorcaserin $((1 R)$-8-chloro-1-methyl-2,3,4,5-tetrahydro-1H-3-benzazepine) and pimavanserin ( $N$-(4-fluorophenylmethyl)- $N$-(1-methylpiperidin-4-yl)- $N^{\prime}$-(4-(2-methylpropyloxy)phenylmethyl)carbamide), and shown below is the consensus-binding pocket of 5-HT receptors.

pharmacologically distinct $5-\mathrm{HT}_{1 \mathrm{~B}}$ and $5-\mathrm{HT}_{2 \mathrm{~B}}$ receptors (refs. 19, 29, and Figure 2), many of the key amino acids essential for ligand binding by the G protein-coupled 5-HT receptors are identical. Until recently, this high degree of structural conservation made it challenging for medicinal chemists to create subtype-selective 5 -HT receptor-active drugs. As is evident from Table 1 , and as has been briefly reviewed earlier, several selective serotonergic drugs have now survived the gauntlet of clinical trials and are approved for treating a number of diseases, including obesity, migraine headaches, psychosis, anxiety, depression, chemotherapy-induced nausea, and even Alzheimer's disease.

In this review, we focus on one newly approved $5-\mathrm{HT}_{2 \mathrm{C}}$-selective antiobesity medication (lorcaserin) and a $5-\mathrm{HT}_{2 \mathrm{~A}}$-selective inverse agonist with efficacy in the dopamine-dependent psychosis of Parkinson's disease (pimavanserin) that has recently been selected for expedited FDA review (see Figure 2 for structures). Currently, there is no approved treatment for this relatively common disorder. Clozapine and quetiapine, which are nonselective inverse agonists at the $5-\mathrm{HT}_{2 \mathrm{~A}}$ receptor are rarely used because of unwanted side effects caused by their actions at other receptors (35).

\section{Lorcaserin - a safe and effective antiobesity drug}

For many decades, it has been clear that 5-HT is a critically important neurotransmitter for the central regulation of appetite and metabolism (36) and that it is the $5-\mathrm{HT}_{2 \mathrm{C}}$ receptor that mediates the anorectic actions of 5-HT (37). The anorectic actions of the withdrawn antiobesity medication fenfluramine are due to the agonist actions of its metabolite norfenfluramine at $5-\mathrm{HT}_{2 \mathrm{C}}$ receptors (38). The combination of fenfluramine and the amphetamine derivative phentermine was demonstrated to be a highly effective appetite suppressant (39), but was withdrawn due an unacceptable rate of valvular heart disease (40). Fenfluramine was also linked to pulmonary hypertension, although the incidence was consider-

ably lower than that of valvular heart disease (41). We now know that both valvular heart disease (42) and pulmonary hypertension (43) are likely due to off-target interactions of fenfluramine's principal metabolite norfenfluramine with the $5-\mathrm{HT}_{2 \mathrm{~B}}$ serotonin receptor (27). Thus, while the parent compound fenfluramine is relatively inactive at $5-\mathrm{HT}_{2 \mathrm{~B}}$ receptors $(42)$, norfenfluramine potently activates $5-\mathrm{HT}_{2 \mathrm{~B}}$ receptors $(42,44)$. Indeed, the $\mathrm{EC}_{50}$ of norfenfluramine is approximately $80 \mathrm{nM}$ for the activation of $5-\mathrm{HT}_{2 \mathrm{~B}}$ receptors in vitro. This concentration is roughly equivalent to plasma levels of norfenfluramine in individuals taking fenfluramine for obesity (18). Thus, Arena Pharmaceuticals set out to create a $5-\mathrm{HT}_{2 \mathrm{C}}$-selective agonist devoid of $5-\mathrm{HT}_{2 \mathrm{~B}}$ agonist activity, predicting that such a molecule would be an effective anorectic agent devoid of cardiovascular side effects. Lorcaserin (also known as APD356) (Figure 2B and ref. 45) satisfied these criteria and was entered into clinical trials for the treatment of obesity.

In 2010, the results from a large phase III clinical trial were published (46), demonstrating that lorcaserin-treated individuals $(10 \mathrm{mg} /$ day) achieved, on average, a 5.8-kg weight loss compared with a $2.2-\mathrm{kg}$ weight loss in placebo-treated patients $(P<0.001)$ (Figure 3A). Both lorcaserin- and placebo-treated individuals were given diet and exercise guidance, with $47.5 \%$ of lorcaserin-treated patients achieving $\geq 5 \%$ weight loss compared with $20.3 \%$ for those treated with placebo (Figure $3 \mathrm{~B}$ ). Importantly, there was no evidence for an increase in clinically significant valvular heart disease in lorcaserin-treated patients compared with those receiving placebo. Similar results were reported in a 1-year trial that examined two doses of lorcaserin (10 or $20 \mathrm{mg} /$ day); again, there was no difference in the incidence of valvular heart disease in placebo- and lorcaserin-treated individuals (2.0\% in both). In both trials, headache, nausea, and dizziness were among the most frequent side effects, and there was no evidence for neuropsychiatric sequelae in either trial $(46,47)$. Nasopharyngitis, sinusitis, and upper respiratory infections were seen more commonly among lorcaserin-treated individuals in one trial (46), but not in the other (47). Lorcaserin appears to achieve its weight-reducing effects by diminishing caloric intake rather than by altering energy expenditure (48).

A

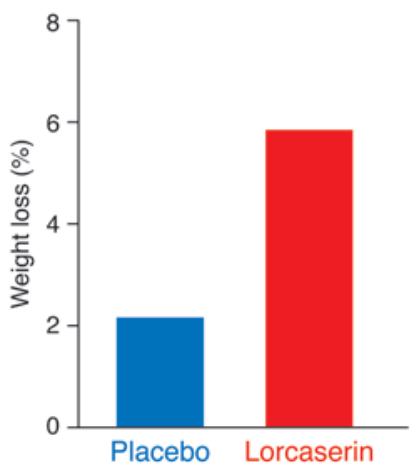

\section{Figure 3}

Lorcaserin induces significant weight loss. (A) Average weight loss versus placebo with lorcaserin treatment $(n=1,538$ in lorcaserin group vs. 1,499 in placebo group; $P<0.001$ ). (B) Percentage of patients in each group who achieved $\geq 5 \%$ weight loss $(P<0.001$ lorcaserin vs. placebo). Data republished with permission from ref. 46. 
A

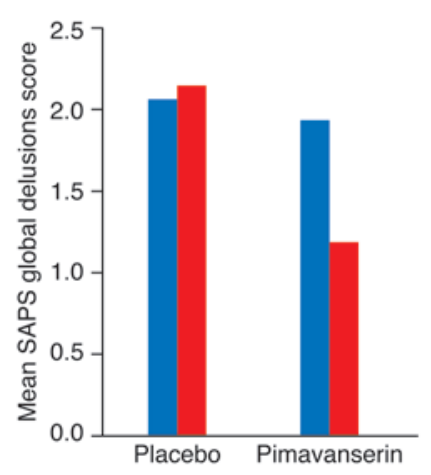

Baseline

28-day

\section{B}

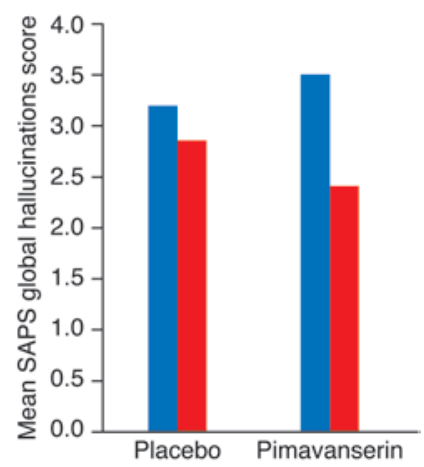

\section{Figure 4}

Pimavanserin significantly improves delusions and hallucinations in PDP. Baseline and 28-day scale for the assessment of positive symptoms (SAPS) of global delusions (A) and hallucinations (B) ratings for 30 patients per group with PDP treated with pimavanserin or placebo $(P<0.05)$, respectively. Data republished with permission from ref. 63 .
Lorcaserin has also been evaluated in obese individuals with type 2 diabetes. In a pivotal study, O'Neill et al. found that lorcaserin induced significant $(P<0.001)$ weight loss and improved glycemic control in individuals with type 2 diabetes compared with that observed in placebo-treated individuals (49). It must be noted that both groups received metformin or sulfonylurea (or both), as well as diet and exercise counseling. Thus, it cannot be concluded without further study that lorcaserin alone would be effective in producing weight loss in obese individuals with type 2 diabetes. As in all other studies, serial echocardiograms were performed, and no significant $(P>0.05)$ drug effect was noted on the incidence of valvular heart disease. Taken together, these results suggest that lorcaserin in combination with diet and exercise counseling can induce clinically significant weight loss and, perhaps, improve glycemic control in obese individuals with type 2 diabetes.

\section{Treating Parkinson's disease psychosis: from clozapine to pimavanserin}

It has long been held that all antipsychotic drugs (APDs) achieve their antipsychotic effect primarily through blockade of dopamine (DA) $\mathrm{D}_{2}$ receptors (50); however, $\mathrm{D}_{2}$ receptor blockade also leads to deleterious extrapyramidal side effects (EPSs) and prolactin elevation (51). At doses of 200 to $900 \mathrm{mg} /$ day, clozapine was found to produce antipsychotic action with minimal EPSs or prolactin elevation in patients with schizophrenia, an atypical profile compared with other APDs $(52,53)$. Comparison of the affinities of typical and atypical APDs for $\mathrm{DA} \mathrm{D}_{1}$ and $\mathrm{D}_{2}$ and $5-\mathrm{HT}_{2 \mathrm{~A}}$ receptors led to the hypothesis that one type of atypical APD could be identified by a higher affinity for $5-\mathrm{HT}_{2 \mathrm{~A}}$ receptors than for $\mathrm{D}_{2}$ receptors $(54)$. Subsequently, a series of drugs that conformed to this hypothesis, including risperidone, olanzapine, and others, were developed for the treatment of schizophrenia (55). Unfortunately, other pharmacologic properties of these broadly acting drugs produced numerous side effects that limited their tolerability (56), including $5-\mathrm{HT}_{2 \mathrm{C}}$ inverse agonism, a major basis for metabolic side effects (57).

Typical APDs, even at ultra-low doses, cause intolerable motor impairment in patients with Parkinson's disease psychosis (PDP), which is a common side effect of L-DOPA and direct-acting DA agonists. By contrast, clozapine, at doses of 12.5 to $75 \mathrm{mg}$ /day, was found to be an effective and tolerable treatment for PDP (35); however, serious, nonmotoric side effects of clozapine limit its use in $\operatorname{PDP}(30,35)$. After an examination of plasma levels of clozapine
(4-6 ng/ml) in responsive PDP patients, it was concluded that clozapine's antagonist (or inverse agonist) activity at $5-\mathrm{HT}_{2 \mathrm{~A}}$ receptors was the basis for its efficacy (58). This provided further support for the suggestion that selective $5-\mathrm{HT}_{2 \mathrm{~A}}$ inverse agonists might be useful as a monotherapy for some psychoses and to potentiate the antipsychotic action of subeffective doses of known APDs $(24,59)$. For these and other reasons, ACADIA Pharmaceuticals developed selective $5-\mathrm{HT}_{2 \mathrm{~A}}$ inverse agonists $(31,35)$. The compound ultimately selected for clinical development was pimavanserin (60). Its pKi $(-\log \mathrm{Ki})$ for the human $5-\mathrm{HT}_{2 \mathrm{~A}}$ receptor is 9.3 , with a 40 -fold selectivity over the $5-\mathrm{HT}_{2 \mathrm{C}}$ receptors and little affinity for $5-\mathrm{HT}_{2 \mathrm{~B}}$ or $\mathrm{D}_{2}$ receptors (60). Pimavanserin demonstrated atypical antipsychotic-like activity in a variety of preclinical models $(37,38,60)$. It also reduced the release of DA in the nucleus accumbens from activated DA neurons (61), which may contribute to its antipsychotic effect, although direct effects on $5-\mathrm{HT}_{2 \mathrm{~A}}$ receptors expressed on glutamatergic and GABAergic neurons may also contribute to the actions of 5- $\mathrm{HT}_{2 \mathrm{~A}}$ inverse agonists $(55,62)$.

Pimavanserin, 20-60 mg/day, was tested in a double-blind, randomized, placebo-controlled, multicenter 28-day trial in 60 patients with L-DOPA-induced PDP (63). The pimavanserin-treated patients showed markedly greater improvement in delusions and hallucinations (Figure 4). Pimavanserin did not differentiate from the placebo with regard to motor impairment, sedation, hypotension, or other side effects $(39,63)$. These results were recently confirmed in a 6-week, randomized, double-blind phase III study involving 198 patients, half of whom received pimavanserin (64). The FDA subsequently indicated that it will evaluate a new drug application (NDA) from ACADIA on the basis of these two studies and other safety data (65). Preclinical studies indicate that pimavanserin may also be useful for treating the psychosis of Alzheimer's disease (66). Pimavanserin has also been shown to potentiate a subeffective dose of the atypical APD risperidone in acutely psychotic patients with schizophrenia, producing a more rapid onset of action than standard-dose risperidone or an equally effective dose of haloperidol, while producing fewer side effects (67). These results are consistent with evidence that pimavanserin, as well as other $5-\mathrm{HT}_{2 \mathrm{~A}}$ inverse agonists, is able to potentiate subeffective doses of atypical, but not typical, APDs in clinically relevant animal models of psychosis and cognitive impairment $(68,69)$. The possibility that pimavanserin is effective as a monotherapy for some patients with schizophrenia is consistent with 
the finding that SR43469B, another 5- $\mathrm{HT}_{2 \mathrm{~A}}$ inverse agonist, was reported to diminish psychotic symptoms more effectively than placebo, but slightly less so than haloperidol, in acutely psychotic patients with schizophrenia (59).

\section{Conclusions}

The approval of lorcaserin by the FDA in June 2012 marks the culmination of many years of basic science investigation in fields as disparate as the central control of appetite and drug-induced valvular heart disease. Thus, the pivotal discoveries that $5-\mathrm{HT}_{2 \mathrm{C}}$ receptors are essential mediators of both appetite (37) and the anorectic actions of fenfluramine (38) and that the closely related receptor $5-\mathrm{HT}_{2 \mathrm{~B}}$ is responsible for drug-induced valvular heart disease $(27,42)$ paved the way for the design of novel serotonergic drugs predicted to be effective in reducing appetite without cardiovascular side effects. Additionally, since it is now well established that drugs can selectively engage either $G$ protein or $\beta$-arrestin signaling $(70,71)$, drugs with selective signaling bias for one pathway over another may have distinct clinical advantages over drugs without functional selectivity (72-75). It will be important to determine whether $5-\mathrm{HT}_{2 \mathrm{C}}$ agonists with signaling bias represent a therapeutic advance over drugs without functional selectivity.

The clinical studies cited here (58) are consistent with preclinical data demonstrating that selective $5-\mathrm{HT}_{2 \mathrm{~A}}$ inverse agonism is a valuable mechanism for treating psychosis with fewer side effects, both as monotherapy and adjunctive treatment. One thing that is unclear, however, is the degree of inverse agonism required for therapeutic efficacy in psychosis and related disorders (76), and future studies examining drugs with a range of antagonist functional selectivity and inverse agonism will be needed to address this point. Finally, additional extensive research is needed to establish the range of disorders in which $5-\mathrm{HT}_{2 \mathrm{~A}}$ inverse agonists can substitute for or augment subeffective doses of APDs. At least for PDP, pimavanserin may be considered a potential next-generation atypical APD.

Taken together, these findings underscore the importance of an in-depth understanding of the biology and pharmacology of specific subtypes of 5-HT receptors and how this may lead to the development of novel treatments with selective clinical efficacies and fewer side effects compared with prior medications.

\section{Acknowledgments}

All primary research reported here from Bryan L. Roth's laboratory was supported by NIH grants (RO1MH61887, U19MH82441, and NIMH Psychoactive Drug Screening Program).

Address correspondence to: Bryan L. Roth, Department of Pharmacology, University of North Carolina Chapel Hill Medical School, CB\#7635, Chapel Hill, North Carolina 27514, USA. Phone: 919.966.7535; Fax: 919.843.5788; E-mail: bryan_roth@med.unc.edu.
1. Rapport MM, Green AA, Page IH. Crystalline serotonin. Science. 1948;108(2804):329-330.

2. Wooley DW, Shaw E. A biochemical and pharmacological suggestion about certain mental disorders. Proc Natl Acad Sci U S A. 1954;40(4):228-231.

3. Gaddum JH, Picarelli ZP. Two kinds of tryptamine receptors. BrJ Pharmacol Chemother. 1957; 12(3):323-328.

4. Dixon RA, et al. Cloning of the gene and cDNA for mammalian beta-adrenergic receptor and homology with rhodopsin. Nature. 1986;321(6065):75-79.

5. Gozlan H, El Mestikawy S, Pichat L, Glowinski J, Hamon M. Identification of presynaptic serotonin autoreceptors using a new ligand: 3H-PAT. Nature 1983;305(5930):140-142.

6. Kobilka FK, et al. An intron-less gene encoding a potential member of the family of receptors coupled to guanine nucleotide regulatory proteins. Nature. 1987;329(6134):75-79.

7. Fargin A, Raymond JR, Lohse MJ, Kobilka BK Caron MG, Lefkowitz RJ. The genomic clone G-21 which resembles a $\beta$-adrenergic receptor sequence encodes the 5-HT1A receptor. Nature. 1988 335(6188):358-360.

8. Kroeze WK, Roth BL. The molecular biology of serotonin receptors: therapeutic implications for the interface of mood and psychosis. Biol Psychiatry. 1998; 44(11):1128-1142.

9. Kroeze WK, Kristiansen K, Roth BL. Molecular biology of serotonin receptors structure and function at the molecular level. Curr Top Med Chem. 2002; 2(6):507-528.

10. Middlemiss DN. Stereoselective blockade at $[3 \mathrm{H}] 5-\mathrm{HT}$ binding sites and at the 5-HT autoreceptor by propranolol. Eur J Pharmacol. 1984; 101(3-4):289-293.

11. Leonhardt S, Herrick-Davis K, Titeler M. Detection of a novel serotonin receptor subtype (5-HT1E) in human brain: interaction with a GTP-binding protein. J Neurochem. 1989;53(2):465-471.

12. Leysen JE, Niemegeers CJ, Tollenaere JP, Laduron PM. Serotonergic component of neuroleptic receptors. Nature. 1978;272(5649):168-171.

13. Leysen JE, Niemegeers CJE, Van Nueten JM, Laduron PM. [3H]-ketanserin ( $\mathrm{R} 41468$ ) a selective
$3 \mathrm{H}$-ligand for serotonin2 receptor binding sites. Mol Pharmacol. 1982;21(2):301-314.

14. Conn PJ, Sanders-Bush E, Hoffman BJ, Hartig PR. A unique serotonin receptor in choroid plexus is linked to phosphatidylinositol turnover. Proc Natl Acad Sci US A. 1986;83(11):4086-4088.

15. Pazos A, Hoyer D, Palacios JM. The binding of serotonergic ligands to the procine choroid plexus: characterization of a new type of serotonin recognition site. Eur J Pharmacol. 1984;106(3):539-546.

16. Dumuis A, Sebben M, Bockaert J. The gastrointestinal prokinetic benzamide derivatives are agonists at the non-classical 5-HT receptor (5-HT4) positively coupled to adenylate cyclase in neurons. Naunyn Schmiedebergs Arch Pharmacol. 1989;340(4):403-410.

17. Bockaert J, Sebben M, Dumuis A. Pharmacological characterization of 5-hydroxytryptamine 4(5-HT4) receptors positively coupled to adenylate cyclase in adult guinea pig hippocampal membranes: effect of substituted benzamide derivatives. Mol Pharmacol. 1990;37(3):408-411.

18. Berger M, Gray JA, Roth BL. The expanded biology of serotonin. Annu Rev Med. 2009;60:355-366.

19. Wang C, et al. Structural basis for molecular recognition at serotonin receptors. Science. 2013; 340(6132):610-614

20. Roth BL, Nakaki T, Chuang DM, Costa E. Aortic recognition sites for serotonin $(5 \mathrm{HT})$ are coupled to phospholipase $\mathrm{C}$ and modulate phosphatidylinositol turnover. Neuropharmacology. 1984; 23(10):1223-1225.

21. Conn PJ, Sanders-Bush E. Selective 5-HT2 antagonists inhibit serotonin-stimulated phosphatidylinositol metabolism in cerebral cortex. Neuropharmacology. 1984;23(8):993-996.

22. Roth BL, Nakaki T, Chuang DM, Costa E. 5-Hydroxytryptamine2 receptors coupled to phospholipase $\mathrm{C}$ in rat aorta: modulation of phosphoinositide turnover by phorbol ester. J Pharmacol Exp Ther. 1986;238(2):480-485.

23. Roth BL, Ciaranello RD, Meltzer HY. Binding of typical and atypical antipsychotic agents to transiently expressed 5-HT1C receptors.J Pharmacol Exp Ther. 1992;260(3):1361-1365.

24. Roth BL, Sheffler DJ, Kroeze WK. Magic shotguns versus magic bullets: selectively non-selective drugs for mood disorders and schizophrenia. Nat Rev Drug Discov. 2004;3(4):353-359.

25. Roth BL, Willins DL, Kristiansen K, Kroeze WK. 5-Hydroxytryptamine2-family receptors (5-hydroxytryptamine2A, 5-hydroxytryptamine2B, 5-hydroxytryptamine2C): where structure meets function. Pharmacol Ther. 1998;79(3):231-257.

26. Roth B, Willins D, Kristiansen K, Kroeze W. Activation is hallucinogenic and antagonism is therapeutic: role of $5-\mathrm{HT}_{2 \mathrm{~A}}$ receptors in atypical antipsychotic drug actions. The Neuroscientist. 1999; 5:254-262.

27. Roth BL. Drugs and valvular heart disease. N EnglJ Med. 2007;356(1):6-9.

28. Huang XP, et al. Parallel functional activity profiling reveals valvulopathogens are potent 5 -hydroxytryptamine(2B) receptor agonists: implications for drug safety assessment. Mol Pharmacol. 2009; 76(4):710-722.

29. Wacker D, et al. Structural features for functional selectivity at serotonin receptors. Science. 2013; 340(6132):615-619.

30. Roth BL, et al. Binding of typical and atypical antipsychotic agents to 5- hydroxytryptamine-6 and 5-hydroxytryptamine-7 receptors. J Pharmacol Exp Ther. 1994;268(3):1403-1410.

31. Weiner DM, et al. 5-hydroxytryptamine2A receptor inverse agonists as antipsychotics. J Pharmacol Exp Ther. 2001;299(1):268-276.

32. Rauser L, Savage JE, Meltzer HY, Roth BL. Inverse agonist actions of typical and atypical antipsychotic drugs at the human 5-hydroxytryptamine(2C) receptor. J Pharmacol Exp Ther. 2001; 299(1):83-89.

33. Kenakin T. Drug efficacy at $G$ protein-coupled receptors. Annu Rev Pharmacol Toxicol. 2002;42:349-379.

34. Keiser MJ, et al. Predicting new molecular targets for known drugs. Nature. 2009;462(7270):175-181.

35. Starkstein SE, Brockman S, Hayhow BD. Psychiatric syndromes in Parkinson's disease. Curr Opin Psychiatry. 2012;25(6):468-472.

36. Blundell JE. Serotonin and appetite. Neuropharmacology. 1984;23(12B):1537-1551.

37. Tecott LH, et al. Eating disorder and epilepsy in mice 
lacking 5-HT2c serotonin receptors. Nature. 1995; 374(6522):542-546.

38. Vickers SP, Clifton PG, Dourish CT, Tecott LH. Reduced satiating effect of d-fenfluramine in serotonin 5-HT(2C) receptor mutant mice. Psychopharmacology (Berl). 1999;143(3):309-314.

39. Weintraub M, Hasday JD, Mushlin AI, Lockwood DH. A double-blind clinical trial in weight control. Use of fenfluramine and phentermine alone and in combination. Arch Intern Med. 1984; 144(6):1143-1148

40. Connolly HM, et al. Valvular heart disease associated with fenfluramine-phentermine. NEnglJ Med. 1997; 337(9):581-588.

41. Brenot F, Herve P, Petitpretz P, Parent F, Duroux P, Simonneau G. Primary pulmonary hypertension and fenfluramine use. Br Heart J. 1993;70(6):537-541.

42. Rothman RB, et al. Evidence for possible involvement of 5-HT(2B) receptors in the cardiac valvulopathy associated with fenfluramine and other serotonergic medications. Circulation. 2000; 102(23):2836-2841.

43. Launay JM, et al. Function of the serotonin 5 -hydroxytryptamine $2 \mathrm{~B}$ receptor in pulmonary hypertension. Nat Med. 2002;8(10):1129-1135.

44. Fitzgerald LW, et al. Possible role of valvular serotonin 5-HT(2B) receptors in the cardiopathy associated with fenfluramine. Mol Pharmacol. 2000; 57(1):75-81.

45. Thomsen WJ, et al. Lorcaserin, a novel selective human 5-hydroxytryptamine2C agonist: in vitro and in vivo pharmacological characterization. J Pharmacol Exp Ther. 2008;325(2):577-587.

46. Smith SR, et al. Multicenter, placebo-controlled trial of lorcaserin for weight management. $N$ Engl JMed. 2010;363(3):245-256

47. Fidler MC, et al. A one-year randomized trial of lorcaserin for weight loss in obese and overweight adults: the BLOSSOM trial. J Clin Endocrinol Metab. 2011;96(10):3067-3077.

48. Martin CK, et al. Lorcaserin, a 5-HT(2C) receptor agonist, reduces body weight by decreasing energy intake without influencing energy expenditure. J Clin Endocrinol Metab. 2010;96(3):837-845.

49. O'Neil PM, et al. Randomized placebo-controlled clinical trial of lorcaserin for weight loss in type 2 diabetes mellitus: the BLOOM-DM study. Obesity (Silver Spring). 2012;20(7):1426-1436.

50. Kapur S, Seeman P. Does fast dissociation from the dopamine $\mathrm{d}(2)$ receptor explain the action of atypical antipsychotics?: A new hypothesis. Am J Psychiatry. 2001;158(3):360-369.

51. Meltzer HY, Stahl SM. The dopamine hypothesis of schizophrenia: a review. Schizophr Bull. 1976; 2(1):19-76.

52. Angst J, Bemte D, Berner P, Heimann H, Helmchen H, Hippius H. Das klinische wirkungsbild von clozapine. Pharmacopsychiaties. 1971;4:201-221.

53. Meltzer HY. Clozapine: balancing safety with superior antipsychotic efficacy. Clin Schizophr Relat Psy- choses. 2012;6(3):134-144.

54. Meltzer HY, Matsubara S, Lee J-C. Classification of typical and atypical antipsychotic drugs on the basis of dopamine D-1, D-2 and serotonin 2 pKi values. J Pharmacol Exp Ther. 1989;251(1):238-246.

55. Meltzer HY, Huang M. In vivo actions of atypical antipsychotic drug on serotonergic and dopaminergic systems. Prog Brain Res. 2008;172:177-197.

56. Meltzer HY. Update on typical and atypical antipsychotic drugs. Annu Rev Med. 2013;64:393-406.

57. Kroeze WK, et al. H1-histamine receptor affinity predicts short-term weight gain for typical and atypical antipsychotic drugs. Neuropsychopharmacology. 2003;28(3):519-526.

58. Meltzer HY, Kennedy J, Dai J, Parsa M, Riley D. Plasma clozapine levels and the treatment of L-DOPA-induced psychosis in Parkinson's disease. A high potency effect of clozapine. Neuropsychopharmacology. 1995;12(1):39-45.

59. Meltzer HY, Arvanitis L, Bauer D, Rein W. Placebocontrolled evaluation of four novel compounds for the treatment of schizophrenia and schizoaffective disorder. Am J Psychiatry. 2004;161(6):975-984.

60 . Vanover KE, et al. Pharmacological and behavioral profile of N-(4-fluorophenylmethyl)-N-(1-methylpiperidin-4-yl)- $\mathrm{N}^{\prime}$-(4-(2-methylpropyloxy)phen ylmethyl) carbamide (2R,3R)-dihydroxybutanedioate (2:1) (ACP-103), a novel 5-hydroxytryptamine (2A) receptor inverse agonist. J Pharmacol Exp Ther. 2006;317(2):910-918.

61. Li Z, Ichikawa J, Huang M, Prus AJ, Dai J, Meltzer HY. ACP-103, a 5-HT2A/2C inverse agonist, potentiates haloperidol-induced dopamine release in rat medial prefrontal cortex and nucleus accumbens. Psychopharmacology (Berl). 2005;183(2):144-153

62. Fribourg $M$, et al. Decoding the signaling of a GPCR heteromeric complex reveals a unifying mechanism of action of antipsychotic drugs. Cell. 2011; 147(5):1011-1023.

63. Meltzer HY, et al. Pimavanserin, a serotonin(2A) receptor inverse agonist, for the treatment of Parkinson's disease psychosis. Neuropsychopharmacology. 2010;35(4):881-892.

64. Cummings JL, et al. Antipsychotic efficacy and motor tolerability in a Phase III placebo controlled study of pimavansserin in patients with Parkinson's disease psychosis. Neurology. 2013;80(19):e530

65. ACADIA Pharmaceuticals, Inc. Web Site. Pimavanserin overview. http://www.acadia-pharm. com/pipeline/pimavanserin.htm. Accessed October 30, 2013.

66. Price DL, Bonhaus DW, McFarland K. Pimavanserin, a 5-HT2A receptor inverse agonist, reverses psychosis-like behaviors in a rodent model of Alzheimer's disease. Behav Pharmacol. 2012; 23(4):426-433.

67. Meltzer HY, et al. Pimavanserin, a selective serotonin (5-HT)2A-inverse agonist, enhances the efficacy and safety of risperidone, $2 \mathrm{mg} /$ day, but does not enhance efficacy of haloperidol, $2 \mathrm{mg} /$ day: comparison with reference dose risperidone, $6 \mathrm{mg} /$ day. Schizophr Res. 2012;141(2-3):144-152.

68. Gardell LR, et al. ACP-103, a 5-hydroxytryptamine $2 \mathrm{~A}$ receptor inverse agonist, improves the antipsychotic efficacy and side-effect profile of haloperidol and risperidone in experimental models. J Pharmacol Exp Ther. 2007;322(2):862-870.

69 . Snigdha S, et al. Attenuation of phencyclidine-induced object recognition deficits by the combination of atypical antipsychotic drugs and pimavanserin (ACP 103), a 5-hydroxytryptamine(2A) receptor inverse agonist.J Pharmacol Exp Ther. 2009; 332(2):622-631.

70. Luttrell LM, et al. Beta-arrestin-dependent formation of beta 2 adrenergic receptor-Src protein kinase complexes. Science. 1999;283(5402):655-661.

71. Beaulieu JM, et al. A $\beta$-arrestin 2 signaling complex mediates lithium action on behavior. Cell. 2008; 132(1):125-136.

72. Noma T, et al. Beta-arrestin-mediated beta1-adrenergic receptor transactivation of the EGFR confers cardioprotection. J Clin Invest. 2007; 117(9):2445-2458.

73. Walters RW, et al. $\beta$-Arrestin 1 mediates nicotinic acid-induced flushing, but not its antilipolytic effect, in mice. J Clin Invest. 2009; 119(5):1312-1321.

74. Allen JA, et al. Discovery of $\beta$-arrestin-biased dopamine D2 ligands for probing signal transduction pathways essential for antipsychotic efficacy. Proc Natl Acad SciU S A. 2011;108(45):18488-18493.

75. Allen JA, Roth BL. Strategies to discover unexpected targets for drugs active at g protein-coupled receptors. Annu Rev Pharmacol Toxicol. 2011;51:117-144.

76. Yadav PN, Kroeze WK, Farrell MS, Roth BL. Antagonist functional selectivity: 5-HT2A serotonin receptor antagonists differentially regulate 5-HT2A receptor protein level in vivo.J Pharmacol Exp Ther. 2011;339(1):99-105.

77. Sumiyoshi T, et al. Enhancement of cognitive performance in schizophrenia by addition of tandospirone to neuroleptic treatment. Am J Psychiatry. 2001;158(10):1722-1725.

78. Zhang M, et al. Preclinical pharmacology and pharmacokinetics of AZD3783, a selective 5-hydroxytryptamine 1B receptor antagonist. J Pharmacol Exp Ther. 2011;339(2):567-578.

79. Brodney MA, et al. Identification of multiple 5-HT(4) partial agonist clinical candidates for the treatment of Alzheimer's disease. J Med Chem. 2012; 55(21):9240-9254.

80. Maher-Edwards G, et al. Double-blind, controlled phase II study of a 5-HT6 receptor antagonist, SB-742457, in Alzheimer's disease. Curr Alzheimer Res. 2010;7(5):374-385.

81. Abbas AI, Hedlund PB, Huang XP, Tran TB, Meltzer $\mathrm{HY}$, Roth BL. Amisulpride is a potent 5-HT7 antagonist: relevance for antidepressant actions in vivo. Psychopharmacology (Berl). 2009;205(1):119-128. 